\title{
ArcheoSciences
}

Revue d'archéométrie

33 | 2009

Authentication and analysis of goldwork

\section{Forgeries and public collections}

Les contrefaçons et les collections publiques

\section{Susan La Niece}

\section{(2) OpenEdition}

\section{Journals}

Electronic version

URL: http://journals.openedition.org/archeosciences/2419

DOI: 10.4000/archeosciences.2419

ISBN: 978-2-7535-1598-7

ISSN: 2104-3728

Publisher

Presses universitaires de Rennes

\section{Printed version}

Date of publication: 31 December 2009

Number of pages: $329-333$

ISBN: 978-2-7535-1181-1

ISSN: 1960-1360

Electronic reference

Susan La Niece, «Forgeries and public collections », ArcheoSciences [Online], 33 | 2009, Online since

10 December 2012, connection on 19 April 2019. URL : http://journals.openedition.org/

archeosciences/2419; DOI : 10.4000/archeosciences.2419 


\title{
Forgeries and public collections
}

\author{
Les contrefaçons et les collections publiques
}

\author{
Susan LA NiECE*
}

\begin{abstract}
Large public collections, however prestigious, inevitably have some forgeries in their storerooms (and occasionally on display) and, although this aspect may seem reprehensible in a publicly funded collection, it is almost inevitable, given the means by which collections are built up by museums. All collectors are vulnerable to forgers who customise their products to tempt the buyer with something that will fill an important gap in their collection, and museums are just as likely to fall for this as private collectors. Forgeries may also enter museum collections as gifts. Museums not infrequently receive bequests from generous patrons, sometimes comprising large numbers of objects, and amongst them a forgery may be included, unrecognised, and may remain unquestioned for many years before coming to the attention of a curator or visiting scholar. This paper presents some case studies of objects in the British Museum for which scientific analysis has demonstrated that either the materials or the technology used in their making are not compatible with their supposed date of manufacture.
\end{abstract}

Résumé : Les collections publiques, bien que prestigieuses, contiennent inévitablement quelques objets modernes dont certains sont exposés. Bien que cela puisse sembler critiquable dans le cas de collections publiques, ceci est inévitable au vu de la façon dont les collections des musées se sont formées au cours des décennies. Tout collectionneur d'art se trouve vulnérable face aux faussaires qui adaptent leurs "produits " pour correspondre à l'attente des acquéreurs; les collectionneurs privés cherchant à combler une lacune importante dans leurs collections, tout comme les musées. Les faux ou les copies modernes, peuvent également être entrés dans les collections publiques par voie de donation. Il est en effet courant que les musées publics reçoivent des donations de personnalités importantes, collections qui sont parfois conséquentes et possédent un ou plusieurs faux. L'authenticité de ces objets ne sera pas questionnée, parfois pendant plusieurs années, jusqu'au moment où, par chance, dans le cadre d'un projet de recherche spécifique, ils soient proprement analysés par des méthodes scientifiques. Cet article présente quelques cas d'études d'objets appartenant à la collection du British Museum, pour lesquels l'étude scientifique a pu prouver que les techniques de fabrications utilisées ne pouvaient pas être compatibles avec leurs dates de fabrication supposées.

Keywords: Analysis, forgery, gold, pastiche, restoration, SEM.

Mots-clés : analyse, faux, or, pastiche, restauration, $M E B$.

\section{INTRODUCTION}

The basic rule of free-market economics - that increased demand will lead to an increase in supply - holds equally true for the supply of antiquities. The supply of genuine antiquities is of course finite, and so the demand has to be met by new 'antiquities'. In $19^{\text {th }}$ century Europe, collecting antiquities became particularly fashionable amongst gentlemen of means (though collecting goes back much earlier), and the output of forgeries of collectibles, which could encompass anything from Renaissance jewellery to instruments of torture of the Spanish Inquisition, turned into an expanding industry (Jones, 1990).

All collectors are vulnerable to forgers who customise their product to tempt the buyer with something that will fill an important gap in their collections, and museums are just as likely as the private collector to fall into the trap. The so-called Tiara of Saitaphernes, who was a historical $3^{\text {rd }}$ century

* Scientific Research, The British Museum - Great Russell Street, London WC1B 3DG, UK. (slaniece@thebritishmuseum.ac.uk) 
BC Scythian king, was purchased by the Musée du Louvre in 1896 (Collignon, 1899; de Pradenne, 1932). In retrospect, it can be observed that the desire to acquire this unique and undoubtedly fine example of the goldsmith's art overcame caution. It soon became known that it had been made by a Russian goldsmith and that the scenes depicted on it were inspired by illustrations from contemporary books on Greek vases, as well as by the tales of the Iliad and Odyssey of Homer and scenes from Scythian life, mixing together styles of different dates.

Unlike private collectors, who almost invariably acquire by purchase, museums may acquire their collections by other routes. The first of these is direct from archaeological excavation, which usually provides the best possible provenance. However, it is not unknown for deception to occur even on excavations, whether as a practical joke, attention seeking or malice.

A second route by which items enter public collections is by donation, either of individual items or of a complete collection (often on the death of a collector, to mitigate taxation). Such large groups of artefacts sometimes include forgeries amongst the genuine pieces, and the forgeries may remain unquestioned for many years before coming to the attention of a curator or visiting scholar. King George III's large collection of coins and medals, deposited at the British Museum in 1825, included a gold Roman coin depicting 'Brutus' (CM B.11447). It was once thought to represent Brutus, the legendary founder of Britain, and was thus considered very desirable at the time, as a missing link in a chronological sequence of coins and medals representing the rulers of Britain. This coin is in fact a close copy in gold of an ancient Roman silver coin depicting Marcus Junius Brutus, the assassin of Julius Caesar.

Any artefact of gold will tend to command a higher price than the equivalent item made of other materials, and in some respects it is easier to produce a convincing 'antiquity' from gold than, for example, from silver. Gold is a particularly difficult material to authenticate scientifically, although this situation is already changing with the development of new techniques (Eugster et al., 2009). The forensic approach to the detection of forgeries relies on finding anachronisms in the materials or techniques used to make them, and a comprehensive database of materials and techniques is therefore of prime importance (Craddock, 2009). The holy grail of a simple test for authenticity may be approaching, but in reality there is as yet no substitute for knowledge acquired by in-depth scientific research into the history of technology, as the following case studies demonstrate.

\section{Early Medieval European Jewellery}

Early medieval European jewellery became particularly popular amongst late $19^{\text {th }}$ /early $20^{\text {th }}$ century collectors, attracted to the artefacts of the ancestors of modern European nations. By the early $20^{\text {th }}$ century, major collections in Europe and the USA contained forgeries of jewellery purporting to be from this period, and also a number of 'improved' genuine artefacts, such as a genuine iron Merovingian buckle (BM1928,0720.1) which has on it a copper-alloy overlay with what was claimed to be the earliest representation of the Crucifixion (Smith, 1928; Baum, 1937). However, radiography revealed the original surface, with its silver-inlaid decoration, beneath the faked additions. When an object has a feature which makes it the earliest or indeed the only example of its type, it merits very close inspection.

A group of more than 30 items of gold work, purporting to originate from northern Italy, from the tomb of the Lombardic King Agilulf (died AD 615) and from that of his queen, Theodelinda (died AD 628), was in fact manufactured about 1929-30. It is no coincidence that it was contemporaneous with the rise to power of Mussolini, as the Treasure was designed deliberately to appeal to a sense of nationalism. Individual items are based on genuine pieces. For example, the buckle is an extravagant combination of features from a number of buckles illustrated in the literature, and the dagger handle is remarkably like those on swords carried by the four emperors in a stone sculpture at San Marco in Venice. The inscription on the dagger bears the name of Theodelinda and the iconography on the other pieces derives from the famous Lombardic helmet fragment depicting her husband King Agilulf, preserved in the Bargello Museum in Florence. Doubts grew about the Treasure on stylistic grounds and it failed to find a buyer, and was thus withdrawn from the market. Dafydd Kidd, then a curator at the British Museum, was interested to see what a scientific examination of these forgeries might reveal of the techniques being employed by the forgers, and in 1988 he purchased two gold mounts for a study. The scientific examination of these two pieces ascertained that the gold was of unusually high purity, and that the solder of the major structural joint of each item contained the element cadmium, an element not found in ancient solders (Meeks and Craddock, 1991). A buckle from the Treasure has red and white glass inlay imitating cloisonné work (Fig. 1). The white glass is opacified with arsenic oxide, which was not used for glass making until the $18^{\text {th }}$ century (Craddock, 2009: 213, 224-5). There are numerous other anachronisms in the technology, although the iron blade of the dagger may well be ancient. 


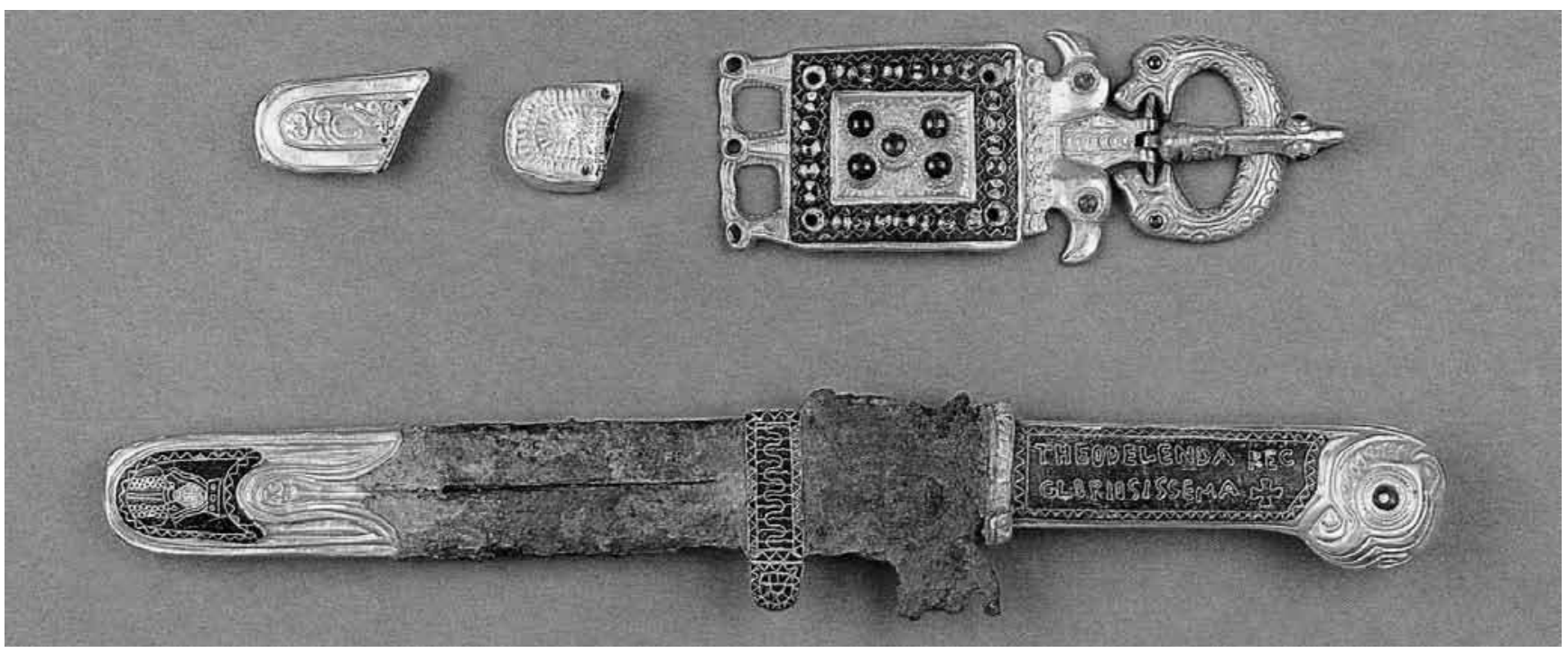

Figure 1: (See colour plate) Items from the Lombard treasure.

Figure 1 : (Voir planche couleur) Objets du trésor des Lombards.

\section{An electroformed 'Pre-Columbian Gold' Ornament}

An extensive survey of the collection of pre-Columbian gold at the British Museum, utilizing a range of scientific techniques, discovered that a fragmentary miniature model of a spouted vessel, in the style of the Chimu culture of pre-Columbian Peru, was not what it appeared to be (BM1947Am21.1) (Fig. 2). The artefact was donated to the British Museum in 1947, and from a visual examination was assumed to be of cast gold alloy; indeed, it was until recently registered as being made of gold. However, X-ray fluorescence analysis and examination by scanning electron microscopy (SEM) showed that the metal is not gold, but pure copper which has been gilded. Furthermore, the columnar microstructure of a small polished cross-section taken from a broken edge indicated that it was neither cast nor worked; rather, it is an electroform, which was subsequently electroplated with a thin layer of gold. Electroforming is a modern method of depositing metal from solution onto the surface of a model by means of an electric current, a technique for making metal items which does not occur until the mid- $19^{\text {th }}$ century.

\section{Egyptian Necklace with Fly Pendants}

An Egyptian-style necklace of unknown provenance was donated to the British Museum in 1939 and was accepted

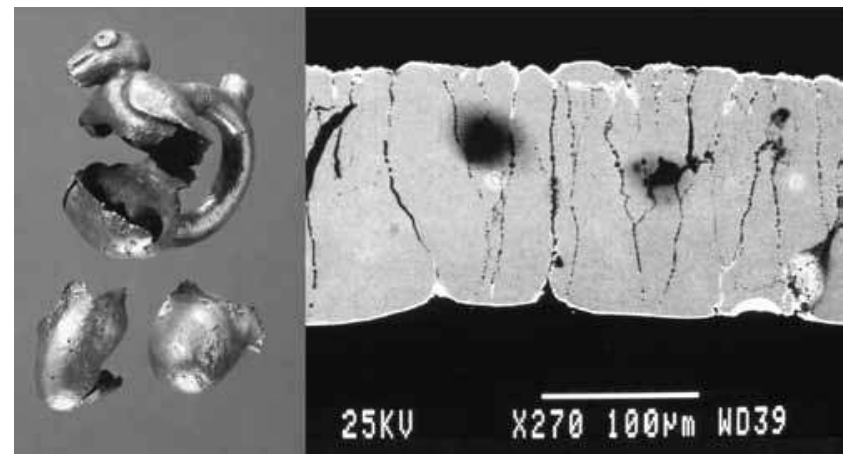

Figure 2: (See colour plate) Fragmentary Chimu-style object (height c. $40 \mathrm{~mm}$ ) with (right) a polished section through the metal revealing the columnar microstructure indicative of electroforming. (SEM BSE image). Figure 2: (Voir planche couleur) Objet fragmentaire de type Chimu (hauteur c. $40 \mathrm{~mm}$ ) avec (à droite) une section polie à travers le métal indiquant la microstructure colonnaire typique de l'électroformage. (image BSE au MEB).

until recently as dating to the New Kingdom (EA65279) (Andrews, 1996). It consists of 38 cast, solid-gold fly pendant amulets and spherical almandine garnet beads of 4-6 $\mathrm{mm}$ in diameter (Fig. 3). The garnet beads are considered peripheral to the question of authenticity, as there is no certainty that the beads were found together with the gold amulets: the stringing is modern and no garnet beads of the size and quality of these could be found amongst the extensive collections of Egyptian beads at the British Museum. A scientific investigation of the piece established that the alloy composition would not be out of place for the alloy ranges found amongst Egyptian New Kingdom 


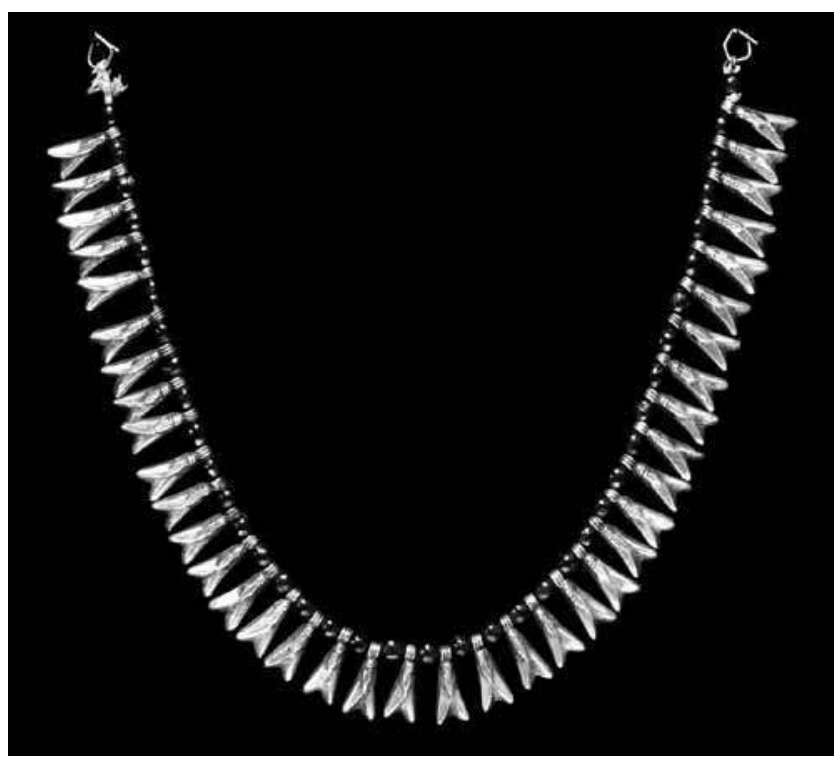

Figure 3: (See colour plate) Garnet and gold necklace with fly amulets, purporting to be New Kingdom period, Egypt.

Figure 3 : (Voir planche couleur) Collier de grenats et or avec des amulettes en forme de mouche, attribué au Nouvel Empire, Égypte.

gold work, with circa $75 \%$ gold, $20 \%$ silver and $5 \%$ copper, but it could equally be described as a modern 18 carat alloy. The 'wear' on the gold is unusually coarse, but it is the manufacturing technique used to make the amulets that is most unusual. Large, cast amulets of Egyptian deities do exist, but sets of small identical pendants such as those on this necklace are usually made of foil and are hollow. In addition, those which are undoubtedly of ancient manufacture are mostly threaded via holes through the body or head of the fly, whereas these have a suspension ring at the top. Lilyquist's study of Egyptian fly amulets identified some examples of modern manufacture, though none of them was cast (Lilyquist, 2003). It is possible that well-provenanced examples of cast solid-gold fly pendants will be excavated in the future and vindicate this piece, but until then its authenticity remains very much in doubt.

The necklace was a bequest, presumably in good faith, and there may have been no intention to deceive by either the donor or even by the maker. It is perfectly possible that it was made as a wearable piece of modern jewellery in the Egyptian style, but over the years, after changing hands, its origins have been lost. If this were the case, it would not of course be defined as a forgery, because forgery implies a deliberate attempt to deceive. A Hellenistic gold strap necklace with pendants acquired by the British Museum in 1872 from Alessandro Castellani does seem to have been made deliberately to deceive (BM1872,0604.651). The Castellani family firm in Rome dealt in antiquities as well as making and restoring jewellery in the antique style so fashionable at the time. A study of the necklace using SEM established that one half of the necklace corresponds to the expectations for genuine Hellenistic Greek goldsmithing, but the wire used on the other half is manufactured by drawing, not by the classical strip-twist method, and is $99 \%$ pure gold (Meeks, 2007). It is therefore likely that this half was made by the Castellani firm. Presumably the original necklace was extensively damaged and had to be restored in the Castellani workshops to pass it off as a near perfect antiquity.

\section{ConClusion}

To quote Mark Jones (1990), the curator of the exhibition 'Fake? The Art of Deception' at the British Museum and now Director of the Victoria and Albert Museum, London, it is "[...] not that the less well informed may sometimes make mistakes, but even the most ... rigorously organised of institutions can and will occasionally be wrong. And this is not simply because knowledge and experience can never be complete, but because perception itself is determined by the structure of expectations that underpins it."

Curatorial judgements of potential purchases cannot be truly objective; all of us are influenced by the times we live in. Some of the famous forgeries of the $19^{\text {th }}$ century may seem obvious to us now, for example, with faces depicted according to the conventions of beauty fashionable in the $19^{\text {th }}$ century. A forensic scientific approach, on the other hand, can be used to determine whether the materials and techniques are consistent with the date attributed to the piece. This of course requires extensive knowledge of what materials and techniques were current during the cultural period concerned, and such knowledge can only be acquired by the scientific study of large numbers of genuine artefacts. It is an advantage of large collections that they are likely to include many genuine pieces of well attested provenance which can be used for comparison. It is a truism that it is impossible to prove that an object is genuine, but scientific analysis is the key to determining whether a piece is restored, a pastiche, enhanced or an outright forgery.

\section{References}

Andrews, C.A.R., 1996. Ancient Egyptian Jewellery. London: British Museum Publications.

Baum, J., 1937. La Sculpture Figurale en Europe à l'Epoque Mérovingienne. Paris, Éditions d'art et d'histoire. 
Collignon, M., 1899. Tiare en or offerte par la ville d'Olbia au roi Säitapharnès. Monuments Piot 6: 5-57.

Craddock, P.T., 2009. Scientific Investigation of Copies, Fakes and Forgeries. Oxford, Butterworth Heinemann.

Eugster, O., Pernicka, E., Brauns, M., Shukolyukov, A., Olive, V. and Roeluin, S., 2009. Helium, uranium and thorium analyses of ancient and modern gold objects: estimates of their time of manufacturing. ArcheoSciences 33: 53-61.

Jones, M., 1990. Fake? The art of deception. Exhibition catalogue. London, British Museum Press.

LILYQuIST, C., 2003. The tomb of three foreign wives of Tuthmosis III. New York, Metropolitan Museum of Art: 299-300.
MeEKs, N.D., 2007. Un collier grec en or ou le pastiche poussé à sa perfection, in F. Gaultier, C. Metzger (eds.), Les bijoux de la collection campana. De l'antique au pastiche. Rencontres de l'École du Louvre 21. Paris, École du Louvre, 127-144.

Meeks, N.D and Craddock, P.T., 1991. Detection of cadmium in gold/silver alloys. Archaeometry 33.

de Pradenne, A.V., 1932. Les Fraudes en Archéologie Préhistorique. Paris, Émile Nourry, 519-573.

Smith, R.A., 1928. The crucifixion on a Frankish buckle. British Museum Quarterly 3: 50-51. 
